\title{
VARIASI CIRI MORFOLOGI DAN POTENSI MAKROALGA JENIS CAULERPA DI PANTAI KONDANG MERAK KABUPATEN MALANG
}

\author{
Murni Saptasari
}

\begin{abstract}
ABSTRAK
Indonesia memiliki keanekaragaman makroalga jenis baik yang bersifat "will crop" maupun beberapa yang telah dibudidayakan Salah satu makroalga dari kelas Chlorophyceae yaitu Caulerpa merupakan sumber daya hayati kelautanPenelitian ini bertujuan untuk menginventarisasi jenis-jenis Caulerpa yang ditemukan di Pantai Kondang Merak. Jenis penelitian ini adalah penelitian deskriptif-eksplorasi. Lokasi penelitian berada di kawasan wana wisata Pantai Kondang Merak yang secara administrasi berada di wilayah Kabupaten Malang. Bahan amatan atau spesimen adalah jenis Caulerpa yang ditemukan di plot pengamatan atau petak cuplikan pada batu karang, pasir serta intensitas cahaya yang cukup Jenis Caulerpa yang ditemukan di Pantai Kondang Merak ada enam jenis termasuk suku Caulerpaceae dan bangsa Siphonales. Ciri secara umum dari Caulerpa adalah keseluruhan tubuhnya terdiri dari satu sel dengan bagian bawah yang menjalar menyerupai stolon yang mempunyai rhizoid sebagai alat pelekat pada subtrat serta bagian yang tegak disebut asimilator.Bentuk asimilator bervariasi tergantung jenisnya.Caulerpa merupakan salah satu jenis alga hijau yang belum banyak dimanfaatkan dan termasuk dalam Feather Seaweed. Feather Seaweed dilaporkan sebagai makroalga yang dapat dimakan, mempunyai zat bioaktif seperti anti bakteri, anti jamur, anti tumor dan bisa digunakan untuk terapi tekanan darah tinggi dan gondok.Penelitian mengenai eksplorasi dan pengolahan Caulerpa perlu dikembangkan mengingat Caulerpa memiliki potensi sebagai bahan obat, pangan dan gizi.
\end{abstract}

Kata Kunci;Caulerpa,variasi morfologi,potensi, pantai Kondang Merak

\section{PENDAHULUAN}

Indonesia sebagai negara maritim mempunyai prospek yang cukup cerah untuk mengembangkan dan memberdayakan sumber hayati kelautan. Salah satu komponen biota yang merupakan sumber daya hayati kelautan adalah makroalga. Indonesia memiliki keanekaragaman jenis baik yang bersifat "will crop" maupun beberapa yang telah dibudidayakan. Makroalga yang umum dijumpai di laut terkenal pula dengan nama rumput laut. Makroalga merupakan salah satu produsen pantai dan jenis-jenis yang ditemukan di pantai berbatu karang umumnya adalah dari kelas Chlorophyceae, Phaeophyceae, dan Rhodophyceae. Salah satu makroalga dari kelas Chlorophyceae yaitu Caulerpa merupakan sumber daya hayati kelautan. Pada umumnya Caulerpa tumbuh di laut dangkal dan di aliran air yang tenang.Marga Caulerpa mempunyai kurang lebih 60 jenis. Menurut Prud'homme Van Reine dan Trono (2001) distribusi Caulerpa secara luas tersebar di pantai daerah tropik sampai subtropik dengan keanekaragaman paling besar adalah di daerah tropik. Pada kawasan timur Indonesia, Caulerpa racemosa dimanfaatkan sebagai bahan makanan. Kelompok makroalga Caulerpa meskipun demikian belum pernah dibudidayakan untuk keperluan komersial. Padahal dalam protoplar Caulerpa dilaporkan mengandung bahan yang bersifat bioaktif seperti caulerpin, asam palmitat, $\beta$-sisterol dan triterpen taraxerol.

Penelitian ini bertujuan untuk menginventarisasi jenis-jenis Caulerpa yang ditemukan di Pantai Kondang Merak. Pantai Kondang Merak merupakan tempat yang ideal untuk pertumbuhan makroalga sebab perairannya yang masuk daerah pasang surut sampai daerah subtidal, subtratnya berupa batu karang, pasir serta intensitas cahaya yang cukup. Menurut Hayati (2009) Pantai kondang Merak merupakan pantai yang relatif tertutup dari masyarakat luar, terdiri atas sejumlah penduduk yang kehidupan sehari-harinya sangat bergantung pada sumber daya alam di pantai. Sebagian besar masyarakat membudidayakan makroalga sebagai sumber penghasilan. Berdasarkan alasan tersebut oleh karena itu perlu diketahui variasi ciri morfologi dan potensi makroalga jenis Caulerpa di Pantai Kondang Merak.

\section{BAHAN DAN METODE}

Jenis penelitian ini adalah penelitian deskriptif-eksplorasi. Lokasi penelitian berada di kawasan wana wisata Pantai Kondang Merak yang 
secara administrasi berada di wilayah Kabupaten Malang. Bahan amatan atau spesimen adalah jenis Caulerpa yang ditemukan di plot pengamatan atau petak cuplikan. Koleksi spesimen ditentukan dengan cara sistematik yaitu pembuatan sampel amatan ditentukan oleh peneliti dengan cara sistematik yaitu dengan membuat transek dari garis pantai ke arah laut yang mempertimbangkan kondisi lingkungan disekitarnya. Identifikasi tumbuhan sampai tingkat jenis menggunakan buku identifikasi Taylor (1972), Trono \& Ganzon-Fortes (1980).

\section{HASIL DAN PEMBAHASAN}

A. Variasi Morfologi Jenis-jenis Caulerpa

Jenis makroalga laut yang ditemukan dapat dilihat pada Tabel 1 di bawah ini.

Tabel 1. Jenis Caulerpa yang Ditemukan di Pantai Kondang Merak

\begin{tabular}{|c|c|c|c|}
\hline No & Bangsa & Suku & Spesies \\
\hline 1. & Siphonales & Caulerpaceae & $\begin{array}{c}\text { Caulerpa serulata } \\
\text { Caulerpa racemosa } \\
\text { Caulerpa cupressoides } \\
\text { Caulerpa crassifolia } \\
\text { Caulerpa peltata } \\
\text { Caulerpa lentifera }\end{array}$ \\
\hline
\end{tabular}

Secara umum makroalga termasuk kedalam tumbuhan berklorofil dengan jaringan tubuh yang relatif tidak mengalami diferensiasi. Tumbuhan makroalga secara keseluruhan disebut talus. Warna talus dari Caulerpa adalah hijau seperti hijau daun, oleh karena itu dikelompokkan kedalam alga hijau (Chorophyceae). Hal ini karena di dalam sel Caulerpa terdapat plastida yang mengandung pigmen klorofil a dan b seperti pada warna hijau daun tumbuhan tingkat tinggi. Menurut Graham (2000) perbedaan warna talus pada alga menimbulkan ciri alga berbeda seperti alga hijau (Chlorophyceae), alga merah (Rhodophyceae), dan alga coklat (Phaeophyceae)

Menurut Smith (1955) Chlorophyceae dibagi menjadi 12 bangsa, salah satunya adalah bangsa Siphonales. Pada umumnya terdapat di laut daerah tropis. Perkembangbiakkan dilakukan secara aseksual dan seksual. Tetapi relative sedikit anggotanya yang membentuk zoospore atau aplanospora. Pada umumnya alga ini membentuk gamet pada cabang yang tidak dapat dibedakan dari bagian vegetatif lainnya. Reproduksi seksual bersifat isogami,anisogami atau oogami.

Bangsa Siphonales dibagi menjadi empat atau lima suku yang disusun dalam suatu deret yang urutannya disesuaikan dengan kompleksitas struktur vegetatifnya atau menurut tingkatan kompleksitas dari struktur gametangianya dan tipe persatuan gamet. Semua Caulerpa yang telah diidentifikasi termasuk suku Caulerpaceae bangsa Siphonales. Bangsa Siphonales memiliki ciri talus merupakan buluh yang tidak bersekat (senositik), bercabang, sekat hanya terbentuk pada masa berkembang biak. Sitoplasma terletak di bagian perifer dari sel, sehingga vakeola sentral tampak terbentang dari ujung ke ujung. Bangsa ini dibagi menjadi 4 atau 5 suku, salah satunya adalah Caulerpaceae yang hanya mempunyai satu marga yaitu Caulerpa (Lee, 1989).
Ciri secara umum dari Caulerpa adalah keseluruhan tubuhnya terdiri dari satu sel dengan bagian bawah yang menjalar menyerupai stolon yang mempunyai rhizoid sebagai alat pelekat pada subtrat serta bagian yang tegak (Gambar 1).

A.

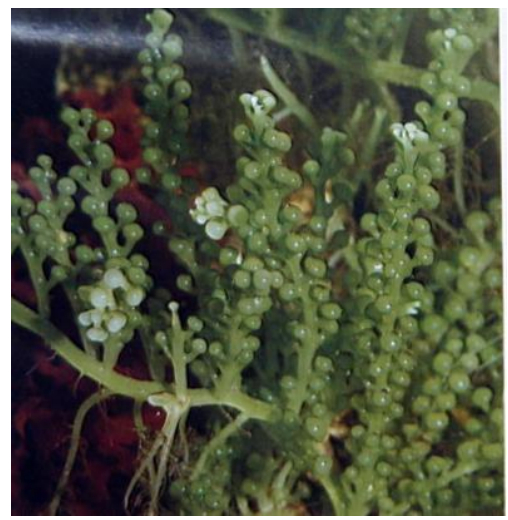

B.

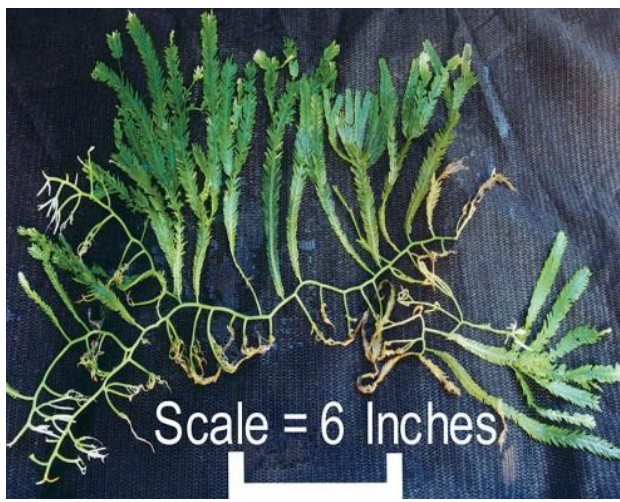

(diambil dari iptek.net.id dan fishchannel.com)

Gambar 1 A.Caulerpa racemosa dan B.Caulerpa cupressoides, 
Bagian yang tegak disebut asimilator karena mempunyai klorofil. Stolun dan rhizoid bentuknya hampir sama dari jenis ke jenis. Sedangkan asimilator mempunyai bentuk bermacam-macam tergantung jenisnya. Caulerpa serrulata asimilatornya memanjang, pipih menyerupai spiral dengan pinggir bergerigi atau bergelombang. Diantara asimilator ada yang membentuk percabangan dan ada pula yang berdiri sendiri tidak bercabang. Asimilator pada Caulerpa cupressoides memiliki asimilator yang memanjang dan bergerigi, sedangkan assimilator pada Caulerpa racemosa berbentuk silindris dengan memiliki bulatan-bulatan ujung merata dan bertangkai panjang (gambar 1).

\section{B. Kondisi Ekologi Caulerpa di Pantai Kondang Merak}

Kondisi ekologi daerah pasang surut Pantai Kondang Merak yaitu suhu air rata-rata $26,5^{\circ} \mathrm{C}, \mathrm{pH}$ air rata-rata 5,6, sedangkan subtrat berupa pasir, lumpur, batu-batuan, termasuk karang dan sebagian besar adalah batu karang. Menurut Svendelius dan Borgersen (Dalam Sabhithah, 1999) Caulerpa berdasarkan habitatnya di bagi menjadi 3 kategori yaitu 1) Jenis yang terdapat dalam lumpur dan tumbuh epitit pada akar mangrove misalnya Caulerpa verticilara, 2) jenis yang terdapat pada subtrat lumpur diperairan dangkal misalnya Caulerpa crassifolia, dan 3) jenis yang menempel pada batu karang misalnya Caulerpa racemosa.

Pada umumnya makroalga Caulerpa yang tumbuh di Pantai Kondang Merak tumbuh bergerombol atau berumpun. Keberadaannya dapat dijumpai di paparan terumbu karang dengan kedalaman 1-200 M. sebagai fitobentik tumbuhan ini hidup menacap atau menempel di subtrat dasar perairan laut seperti karang mati, potongan karang, pasir dan pasir-lumpur. Pertumbuhan bersifat epifilitik atau saprofitik dan kadang berasosiasi dengan tumbuhan umum. Hal ini sesuai dengan pendapat Kadi (1995) bahwa makroalga hijau lebih banyak dijumpai di paparan terumbu karang dengan kedalaman 1-200 m Pada umumnya makroalga bersifat stenohalin dan tidak dapat tumbuh pada daerah dengan salinitas rendah kurang dari $25 \%$.

Menurut hasil penelitian yang dilakukan menunjukkan Caulerpa banyak dijumpai pada tempat yang terlindungi dengan air yang jernih, aliran tidak terlalu kuat arusnya dan bagian dasar halus karena adanya sedimentasi. Prud'homme Van Reine dan Trono (2001) menyatakan bahwa keanekaragaman Caulerpa paling tinggi di daerah tropik yaitu di zona culitoral dan berkurang pada zona bagian dalam. Pada zona sublitoral Caulerpa tumbuh menempel pada karang mati atau merayap di bawah kanopi coral.

Caulerpa racemosa tumbuh pada bagian tengah sampai bagian bawah zona eutorial dengan subtrat lumpur atau pasir. Tetapi ditemui juga tumbuh soliter pada batuan mati. Caulerpa serulata tumbuh pada subtrat pasir dan panjangnya dapat mencapai $2 \mathrm{~m}$. menurut Prud'homme Van Reine dan Trono (2001) distribusi vertikal Caulerpa sangat luas. Seperti misalnya Caulerpa racemosa ditemukan pada 20-30 m kedalamannya dan Caulerpa crassifolia mencapai 90 m kedalamannya.

\section{Potensi Caulerpa di Pantai Kondang Merak} Berdasarkan hasil observasi menunjukkan jenis Caulerpa di Pantai kondang Merak dikonsumsi secara lokal oleh masyarakat sebagai bahan sayur atau lalapan dan belum dibudidayakan secara komersial. Padahal produk Caulerpa ini banyak bermanfaat bagi kebutuhan manusia dan memiliki nilai pangan dan gizi antara lain kandungan kimianya yang berupa karbohidrat, protein, vitamin dan mineral. Kadar dan kualitas produk tersebut bervariasi menurut jenis, lokasi dan teknik pengolahan.

Caulerpa merupakan salah satu jenis alga hijau yang belum banyak dimanfaatkan dan termasuk dalam Feather Seaweed. Feather Seaweed dilaporkan sebagai makroalga yang dapat dimakan, mempunyai zat bioaktif seperti anti bakteri, anti jamur, anti tumor dan bisa digunakan untuk terapi tekanan darah tinggi dan gondok. Zat bioaktif adalah zat yang termasuk meabolit sekunder yang bersifat aktif secara biologi dan dapat digunakan untuk industri pangan dan farmasi (BBRP2B, 2010).

Anam (1999) menyatakan kandungan kimia Caulerpa sertularioides telah diteliti memiliki lima senyawa dan telah diisolasi dari ekstrak n-heksana yaitu Caulerpin, O-sitosterol asam palmitat dan dua senyawa lain yang diduga sebagai steroid dan hodrokarbon. Ekstrak dari etil asetat mengandung caulerpin dan siklotetra dekana, serta dari ekstrak metanol diidolasi caulerpin dan suatu senyawa yang diduga hidrokarbon tidak jenuh. Collins (1978) menyatakan zat caulerpicin dan caulerpin dapat diisolasi dari Caulerpa racemosa, Caulerpa sertulariodes, dan Caulerpa lentifera. Kandungan ini dapat diketahui apabila tallus terluka menunjukkan warna jingga dan kemudian akan timbul tonjolan sehingga menyebabkan degenerasi disekitar luka tersebut.

Menurut Yangthong (2009) Caulerpa racemosa var. macrophysa memiliki aktivitas antioksidan. Sedangkan Santoso (2004) dalam penelitiannya mengenai aktifitas antioksidan pada beberapa makroalga di Indonesia 
menunjukkan Caulerpa sertulariodes bersifat sebagai antioksidan dan ektrak metanol dari Caulerpa sertulariodes mengandung tiga macam catechin (fiavanol) yaitu gallo catechin, epicatechin dan catechin gallat. Catechin merupakan hasil metabolit tanaman yang termasuk dalam famili flavonoid dan berfungsi sebagai antioksidan.

Menurut Insan dan Widyartini (2008) Caulerpa racemosa diketahui bersifat racun terhadap beberapa organisme laut. Hasil dan ekstrak Caulerpa dapat diisolasi senyawa kimia seperti caulerpicin, caulerpin dan sterol. Caulerpicin menimbulkan rasa pedas dan menyebabkan efek anesthesia yang ringan bila ditempelkan pada mulut sehingga aktifitas neurotropik ini mempunyai nilai klinik. Izzati, M (2007) berdasarkan hasil penelitian menunjukkan Caulerpa racemosa memiliki aktivitas antibakteri terhadap tiga jenis bakteri patogen yaitu Pseudomonas pavanaceae, Pseudomonas syntata, dan Pseudomonas tetrolens. Ketiga jenis bakteri patogen ini sering menyerang udang windu.

Tumbuhan yang digunakan sebagai obat selama ini kebanyakan dari tumbuhan darat sedangkan tumbuhan yang berasal dari laut seperti makroalga belum banyak mendapatkan perhatian. Indonesia memiliki wilayah perairan yang sangat luas tentunya memiliki keanekaragaman jenis yang tinggi dan kemungkinan berpotensi sebagai obat. Menurut Rasyid A (dalam Insan dan Widyartini, 2008) beberapa jenis makroalga di Indonesia dapat digunakan sebagai obat, tetapi saat ini mengalami kendala karena penelitian mengenai eksplorasi dan pengolahannya belum berkembang oleh karena itu pemanfaatannya sampai saat ini sangat terbatas.

\section{KESIMPULAN}

1. Jenis Caulerpa di Pantai Kondang Merak ada enam jenis yang memiliki variasi morfologi yang menarik, karena perawakannya sama keseluruhan terdiri dari bagian bawah yang menjalar dan mempunyai rhizoid tetapi bentuk asimilatornya bervariasi. tergantung jenisnya.

2. Jenis Caulerpa di Pantai Kondang Merak memiliki potensi untuk dikembangkan karena banyak bermanfaat bagi kebutuhan manusia serta memiliki nilai pangan, gizi dan obat.

\section{SARAN}

Penelitian mengenai eksplorasi dan pengolahan Caulerpa perlu dikembangkan mengingat Caulerpa memiliki potensi sebagai bahan obat, pangan dan gizi.

\section{DAFTAR RUJUKAN}

Aslan, Laode, 1990. Budidaya Rumput Laut. Yogyakarta: Kanisius.

Balai Besar Riset Pengolahan Produk dan Bioteknologi Kelautan dan Perikanan (BBRP2BKP), 2010. Manfaat dan Kandungan Kimia Caulerpa.

http//www.bbrp.2b.dkp/kl.sn iptek/Do.Manfaat.

Hayati, A dan Insan, M, 2009. Keanekaragaman Makroalga di Pantai Kondang Merak Kabupaten Malang. Makalah Seminar Nasional Biologi XX dan Konggres PBI XIV di Universitas Maulana Malik Ibrahim Malang. 24-25/III 2009.

Insan dan Widyartini, 2008. Jenis-jenis Rumput Laut yang Berpotensi Sebagai Obat yang tumbuh pada Berbagai Subtrat di Pantai Ranababakan Nusakambangan Cilacap.

Izzati, M, 2007. Skreening Potensi Anti Bakteri pada Beberapa Spesies Rumput Laut terhadap Bakteri Patogen pada Udang Windu. Jurnal Bioma. Vol. 9. No. 2

Prud'homme Van Reine, W. F dan Trono, G. C, 2001. Plant Resource of South-East Asia. Backbuys Pub, Leiden.

Sabbithah, S. 1999. Taksonomi Tumbuhan I ALGAE. Laboratorium Taksonomi Tumbuhan. Fakultas Biologi. Yogyakarta. Tidak diterbitkan.

Yangthong, M, Mutadilok dan Towatana. Antioxidant Activities of Four Edible Seaweeds from the Southern Coast of Thailand. Jurnal Plant Food. Hom. Nutr. 2009. 64 (3). 